\title{
ニッケルークロムメッキの耐食性に関する電気化学的研究*
}

\author{
古川 直治** 林 忠 夫** 石田 武男**
}

\section{Electrochemical Studies on Corrosion Resistance of}

\section{Nickel-Chromium Electroplates}

\author{
Naoji Furukawa, Tadao Hayashi and Takeo Ishida
}

The electrochemical studies have been made in order to know the corrosion resistance of nickelchromium (Ni-Cr) electroplates. It was found that chromium plate tends to become passive at less noble potentials than the nickel in acid sulfate solution, and the rate of dissolution of the former is very small compared with the nickel electroplate.

The nickel corrodes somewhat more rapidly than it would in the absence of chromium, because of the galvanic cell created by chromium covering to nickel. In the initial stage of the corrosion reaction, the rate of attack of the nickel was found to be affected by the numbers of the defects of chromium

\section{1. 緒言}

現在，鉄鋼および亜鉛ダイカストに対する防食および 装飾を目的としてニッケルークロムあるいは銅ーニッケ ルークロムメッキが広く用いられている。

このような複層メッキ系として, 最近, 二層ニッケル メッキが実用化されているが，これは硫黄を含まない半 光沢ニッケルメッキ上に硫黄を含む反応性の高い光沢二 ッケルメッキを行ない，下地のニッケルの腐食を抑制す ることにより耐食性をよくすることを目的としてい る1)。一方，クロムメッキ法においてもいろいろな改良 がなされ，たとえばマイクロクラッククロムメッキでは クラックを微細化することによりニッケルメッキの局所 的な腐食を防ぎ，耐食性を向上させるのを目的としてい る2)。

一般に, ニッケルークロムメッキの耐食性の 評価は大 気暴露試験ならびにいわゆる加速腐食試験によって行な われているが, 最近, 電気化学的測定による分極曲線か らその耐食性を予測できることが報告されている3,4)。 このような耐食試験に用いられる溶液には種々のイオン が存在するので，測定した電流-電位曲線に 基づいて二 ッケルークロムメッキの腐食機構あるいは耐食性を正し く評価することは困難である。一方，T.P. Hoar5) およ

* 昭和 40 年11月 9 日 第 12 回窝食防食討論会（名古屋）において発 表

** 大阪府立大学工学部応用化学教室（堺市百舌鳥梅町 4 丁） coatings and also by the nature of nickel coating.

The microscopic examination of the cross section of $\mathrm{Ni}-\mathrm{Cr}$ electroplate which have been subjected to the electrochemical measurement showed that corrosion pits in the nickel layer were distributed rather uniformly in the case of microcracked chromium, but randomly in the conventional chromium plate.

The corrosion resistance of the double-layer nickel can be explained by the fact that the sulfurcontaining nickel plated on the sulfur-free nickel will undergo preferential attack and is effective in the retardation of the rate of penetration into the double-layer nickel coatings.

び W.A. Wesley6) によると, 腐食環境においてニッケ ルークロムメッキに認められる孔食現象は電気化学的な ものであることが早くから指摘されているが，腐食孔の 発生および成長機構については現在なお不明な点が多 い。腐食孔の形態ならびに分布状態については, 従来加 速腐食試験あるいは大気暴露試験による複層メッキ試料 についての多くの報告があるが1,7), 孔食現象の電気化学 的測定については研究が少ない。

本研究は, ニッケルークロムメッキ系の腐食機構を明ら かにし，さらに耐食性の評価方法を検討することによっ て耐食性のよい複層メッキ法を確立する目的で, ニッヶ ルメッキ,クロムメッキおよびニッケルークロムメッキ試 料について硫酸中における分極測定を行なうとともに， 電気化学的孔食現象について検討した。

\section{2. 実験方法}

\section{$2 \cdot 1$ 分極測定}

(a) 試 料

分極測定に用いたニッケルメッキ，クロムメッキおよ びニッケルークロムメッキは表 1 に示したよらなメッキ 浴を用いて作成した。

ニッケルメッキの素地には電解ニッケル板（志村化工 製品）を用い, エメリ一研摩 $(0 / 5)$, バフ研摩, 電解脱 脂および水洗ののち $30 \mu$ の厚さのニッケルメッキを行 なった。 
表 1 試料の作成条件

\begin{tabular}{|c|c|c|c|c|c|}
\hline 料 & 喜 & 加㓩 & $\mid \begin{array}{c}\text { 電流密度 } \\
\mathbf{c} / \\
\left.\mathrm{cm}^{2}\right)\end{array}$ & $\begin{array}{l}\text { 温度 } \\
\left({ }^{\circ} \mathrm{C}\right)\end{array}$ & メッキの特靯 \\
\hline \multirow{3}{*}{$\begin{array}{l}\text { ニッケル } \\
\text { メッキ }\end{array}$} & A & ワット浴 ${ }^{*}$ & 0.03 & 45 & 無光沢, 高純度 \\
\hline & B & $\begin{array}{l}\text { ワット浴+1,5-ナフ } \\
\text { タリジシルホン酸 } \\
\text { ナトリウム } \\
(5 \mathrm{~g} / l)\end{array}$ & 0.03 & 45 & $\begin{array}{l}\text { 半光沢. 硫黄含 } \\
\text { 有量 } \\
0.023 \%\end{array}$ \\
\hline & $\mathrm{C}$ & $\begin{array}{c}\text { ワット浴+チ乔层素 } \\
\left(5 \times 10^{-4}-M / l\right)\end{array}$ & 0.03 & 45 & $\begin{array}{l}\text { 光沢, 硫黄含有 } \\
\text { 量 } \\
0.35 \%\end{array}$ \\
\hline \multirow{5}{*}{$\begin{array}{lll}\eta & \square & 厶 \\
x & ッ & \neq\end{array}$} & $D_{1}$ & \multirow{3}{*}{ サージェント浴** } & \multirow{3}{*}{0.20} & $D_{1}, 35$ & \multirow{3}{*}{$\begin{array}{l}\text { メッキ温度が高 } \\
\text { くなるれで } \\
\text { クラックの数が } \\
\text { 少なくなる゙な }\end{array}$} \\
\hline & $\mathrm{D}_{2}$ & & & $\mathrm{D}_{2}, 45$ & \\
\hline & $\mathrm{D}_{3}$ & & & $D_{3}, 55$ & \\
\hline & $\mathrm{E}$ & $\begin{array}{l}\text { サー該ンント浴+セ } \\
\text { レン酸ナトリ穴ム } \\
(0.018 \mathrm{~g} / l)\end{array}$ & 0.20 & 45 & $\begin{array}{l}\text { マイクロクラッ } \\
\text { ククロムメッキ }\end{array}$ \\
\hline & $\mathrm{F}$ & $\begin{array}{ll}\text { ク口ム酸 } & 270 \mathrm{~g} / l \\
\text { 硫 } 1.7 \mathrm{~g} / l\end{array}$ & 0.20 & 55 & $\begin{array}{l}\text { クラックフリー } \\
\text { クロムメッキ }\end{array}$ \\
\hline 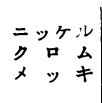 & G & \multicolumn{4}{|c|}{ 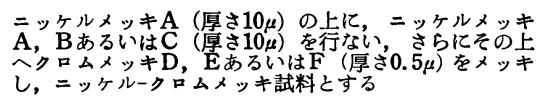 } \\
\hline
\end{tabular}

* $\mathrm{NiSO}_{4} \cdot 7 \mathrm{H}_{2} \mathrm{O} ; 240 \mathrm{~g} / l, \mathrm{NiCl}_{2} \cdot 6 \mathrm{H}_{2} \mathrm{O} ; 45 \mathrm{~g} / l, \mathrm{H}_{3} \mathrm{BO}_{3} ; 30 \mathrm{~g} / l$ $\mathrm{pH}=4.0$

** $\mathrm{CrO}_{3} ; 250 \mathrm{~g} / l, \mathrm{H}_{2} \mathrm{SO}_{4} ; 2.5 \mathrm{~g} / l$

クロムメッキほ, 電解研摩した圧延銅板の上に約 $60 \mu$ の厚さのクロムメッキを行なったのち, 素地銅板をク口 厶酸 $250 \mathrm{~g} / l$, 硫酸 $30 \mathrm{~g} / l$ を含む溶液中で溶解し, 測定 試料とした。

ニッケルークロムメッキの素地にはエメリー研摩した 低炭素鋼板 $(0.2 \mathrm{~mm})$ を用いた。最初, ワットニッケ ル浴を用いて $10 \mu$ の厚さのニッケルメッキを行ない, さらにその上へ各種のニッケルメッキ $(\mathrm{A} \sim \mathrm{C})$ を $10 \mu$, 次いでクロムメッキ $(\mathrm{D} \sim \mathrm{F})$ を $0.5 \mu$ の厚さにメッキ し測定試料を作成した。

なお，これらのメッキ試料は，測定面積が一定になる ように絶縁塗料を用いて不要部分をおおった。

(b) 測定方法ならびに測定条件

メッキ試料の分極測定は定電位法8) によって行なっ た。電位は直流増幅型定電位電解装置（日亜計器製, HP -E型）を用いて設定した。測定回路ならびに電解槽の模 式図を図 1 に示した。

分極電位の測定には照合電極として飽和甘承電極（S CE）を用い，分極測定の場合には対極として白金板を用 いた。

電解液は, 硫酸ナトリウム溶液と硫酸を用い, 硫酸イ オン濃度 $0.05 M / l, \mathrm{pH}=1.1$ となるように作成した。 測定はすべて, 窒素飽和, 静止状態, 温度 $25^{\circ} \mathrm{C}$ の一定 条件のもとで行なった。

\section{2 腐食形㷫の観察}

分極測定に用いたニッケルークロムメッキ試料を樹脂 の中に埋めこみ, 試料の断面をエメリーで研摩し, 硝酸

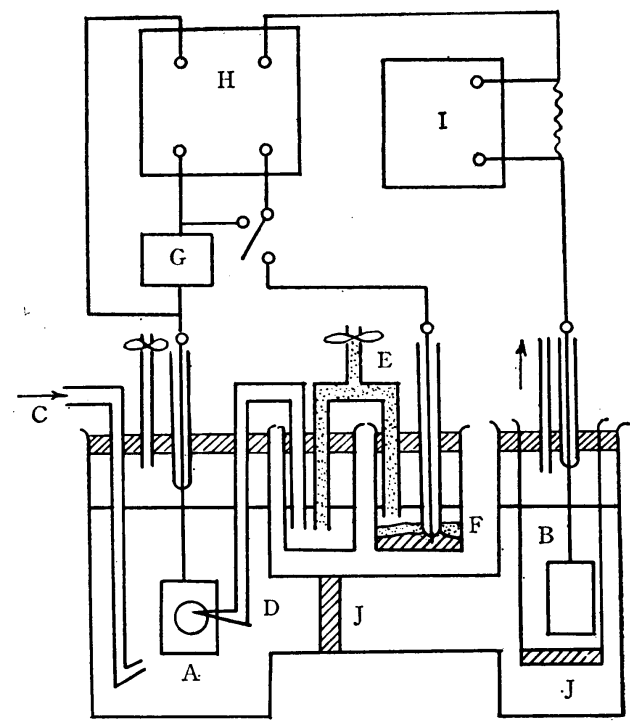

A：試料極， B：白金対極，C：窒素導入管 D: Luggin 毛管, E: 硫酸カリウム塩橋, F：的和甘承電極, G：自倒加電圧装置,

$\mathrm{H}$ : ポテンシオスタット， I：自働記録計, $\mathrm{J}:$ ガラスフィルター

図 1 電解槽および定電位電解回路の模式困

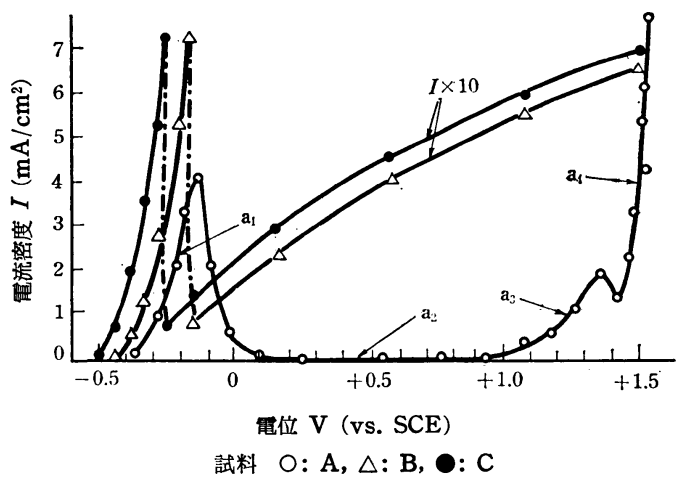

図 2 ニッケルメッキの分極曲線

$100 \mathrm{~g}$ ，酢酸 $30 \mathrm{~g}$ を含む溶液中で数秒間エッチングした のち，金属顕微鏡を用いて腐食形態および腐食孔の発生 状態を観察した。

\section{3. 実験結果ならびに考察}

図 2 に $0.05 M / l \mathrm{Na}_{2} \mathrm{SO}_{4}-\mathrm{H}_{2} \mathrm{SO}_{4}$ 溶液における 各種の ニッケルメッキの定電位アノード分極曲線を示した。ワ

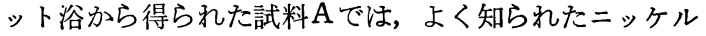
の活性態 $\left(a_{1}\right)$, 不働態 $\left(a_{2}\right)$, 過不働態 $\left(a_{3}\right)$ および酸 素発生 $\left(a_{4}\right)$ の反応に相当する電流-電位曲線が認めらわ,

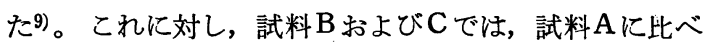
自然電極電位ならびに活性態における分極曲線が果な電 位方向に移行しており, 試料の溶解電流の值が著しく大 きいことがわかった。このように試料BおよびCは試料 $\mathrm{A}$ と比べて腐食速度が大きく，不働態化が抑制されるも 
のと考えられる。このような現象は Raub10) が各種の二 ッケルメッキ試料について得た結果と類似しており, メ ッキ浴中の添加剤加ら共析した硫黄あるいは炭素化合物 がニッケルの腐食反応に著しい影響を与えているものと 考えられる。とくに，試料 $\mathrm{B}$ およびC $\mathrm{C}$ 分極曲線が $\mathrm{A}$ と 比べて果な電位側に移行するのは, メッキ中の硫黄の影 響により，局部アノード反応の電流-電位曲線が果に移行 するためと考えられる。

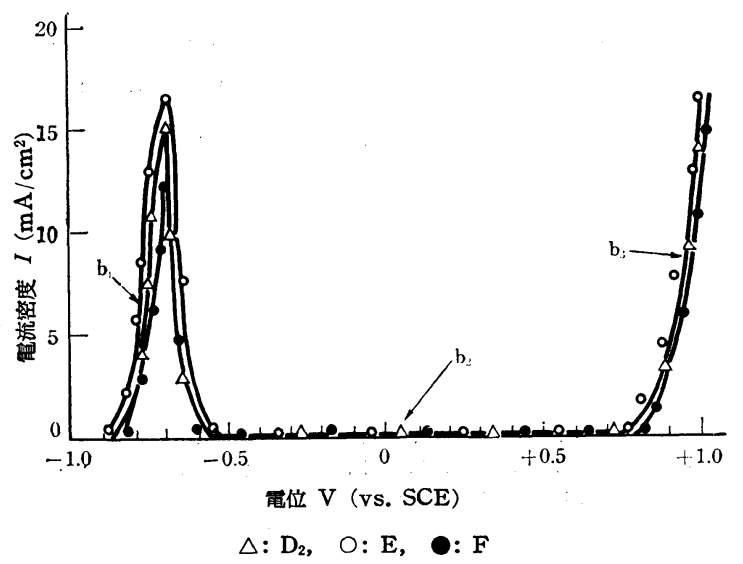

図 3 クロムメッキの分極曲線

図 3 亿は，3 種のクロムメッキの定電位フノード分極 曲線を示した。試料 $\mathrm{D}_{2}, \mathrm{E}$ および $\mathrm{F}$ に注クロムの活性 態 $\left(b_{1}\right)$, 不働態 $\left(b_{2}\right)$ および過不働態 $\left(b_{3}\right)$ の反応に対

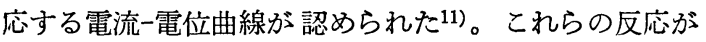
起こる電位は,クロムメッキの種類によってかわらない。 活性態における試料の溶解電流の值が $\mathrm{E}, \mathrm{D}_{2}, \mathrm{~F}$ の順序 で小さくなるが，これはクロムメッキ表面のクラックの 数がメッキ条件（表 1) によって少なくなる順序（E> $\left.\mathrm{D}_{2}>\mathrm{F}\right)^{12)}$ と一致しており，試料の表面構造の影響があ らわれているものと考光られる。

図4にはいろいろなニッケルークロムメッキ試料につ いて測定した定電位アノード分極曲線を示した。ここで

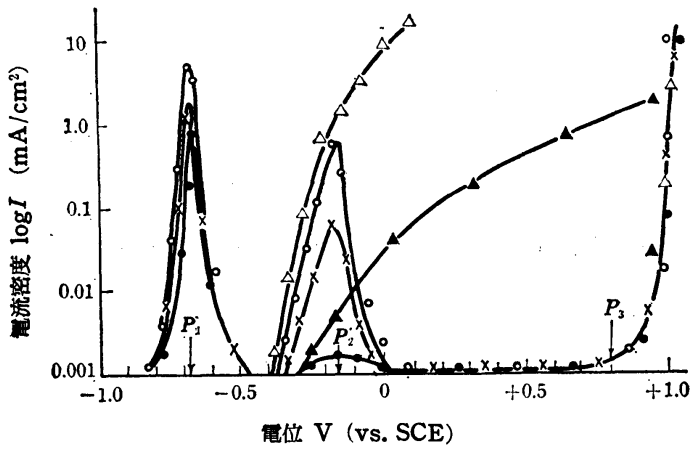

陚料 $G: \bullet: A-F, \quad x: A-D_{2}, O: A-E$, $\Delta: \mathrm{B}-\mathrm{F}, \triangle \mathrm{B} \mathrm{B}-\mathrm{E}$

图 4 ニッケルークロムメッキの分極曲線
試料 $\left(\mathrm{A}-\mathrm{D}_{2}\right)$ の分極曲線における電位 $P_{1}($ 約 $-0.69 \mathrm{~V})$, $P_{2}$ (約 $\left.-0.15 \mathrm{~V}\right)$ および $P_{3}($ 約 $+0.80 \mathrm{~V})$ は，それぞれク ロムメッキの活性態のピーク電位約 $-0.68 \mathrm{~V}$ ，ニッケル メッキの活性態のピーク電位約 $-0.14 \mathrm{~V}$ およびクロムメ ッキの過不働態化電位約 $+0.83 \mathrm{~V}$ に近い。

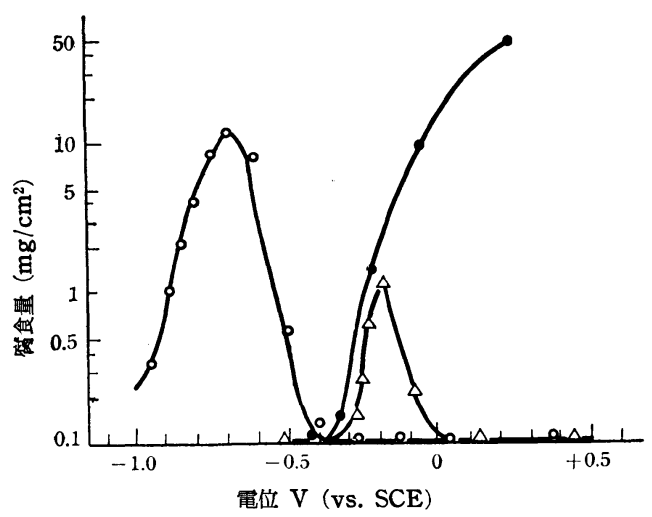

試料 $\mathrm{G} ： \bigcirc ： \mathrm{~A}-\mathrm{E}$ あるいは $\mathrm{B}-\mathrm{E}$ におけるク口ムの窝食量 $\triangle: A-E$ とおけるニッケルの窝食量 ○: B-Eにおけるニッケルの窝食量

図 5 ニッケルークロムメッキにおけるニッケル ならびにクロムの腐食量

いま，図 5 に約 $-1.0 \mathrm{~V}$ から $+0.5 \mathrm{~V}$ (vs. SCE) の電 位領域における ニッケルークロムメッキ試料の腐食量を それぞれニッケルおよびクロムについて示したが，クロ ムメッキの溶解は自然電極電位（約 $-0.82 \mathrm{~V}$ ) より果な 電位から約 $-0.4 \mathrm{~V}$ の電位領域で起こることがわかる。 またニッケルメッキA注約 $-0.34 \mathrm{~V} \sim-0.14 \mathrm{~V}$ におい て比較的溶解量が大きく, さらにニッケルメッキBでは 約 $-0.4 \mathrm{~V}$ から溶解速度が大きくなり, 電位が貴になる とともに溶解量が著しく増大した。このことから，ク口 ムメッキの自然電極電位の近傍においては局部カソード 反応が比較的大きいが，約 $-0.4 \mathrm{~V}$ より貴な電位では表 面皮膜が生じクロムメッキが不働態化状態となるものと 考えられる。

図 2 および図 3 に示したように, ニッケルメッキの活 性態電位はクロムメッキの不働態電位領域に対応してい ることがわかる。このことから図 4 の $P_{2}$ 付近の電位に おけるニッケルメッキの腐食速度は，クロムメッキと比 べて著しく大きくなり，ニッケルメッキの腐食は，ク口 ムメッキのクラックあるいはピンホールなどの欠陥を通 じて起こるものと考元られる。

图6，图7および图8は，いろいろなニッケルークロム メッキ試料をー $0.2 \mathrm{~V}$ (vs. SCE) において電解した場合 のニッケルメッキの腐食量の時間的変化を示した。

図 6 に打いて, 二ッケルメッキAは電解開始後約 5 分 以上では窝食量が時間に対して直線的に増大しており， 腐食速度は $(\mathrm{A}-\mathrm{E}),\left(\mathrm{A}-\mathrm{D}_{1}\right),\left(\mathrm{A}-\mathrm{D}_{2}\right),(\mathrm{A}-\mathrm{F})$ の順 


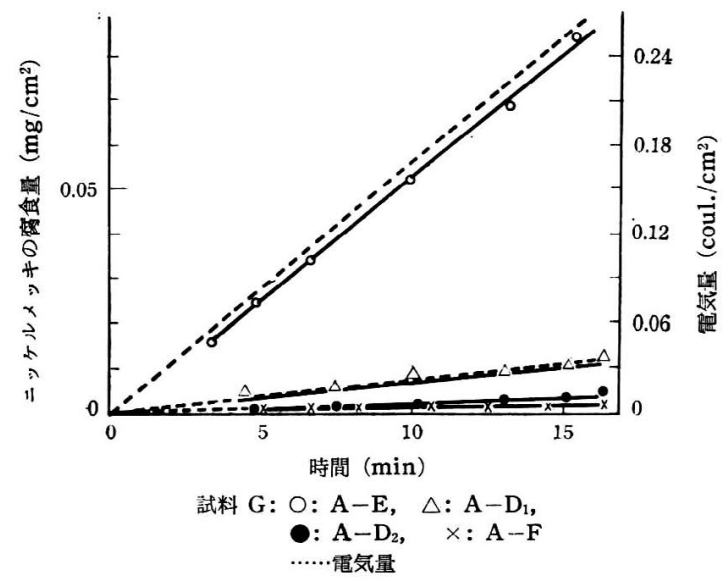

図 6 ニッケルークロムメッキにおけるニッケル の腐食速度

$$
E=-0.2 \mathrm{~V}
$$

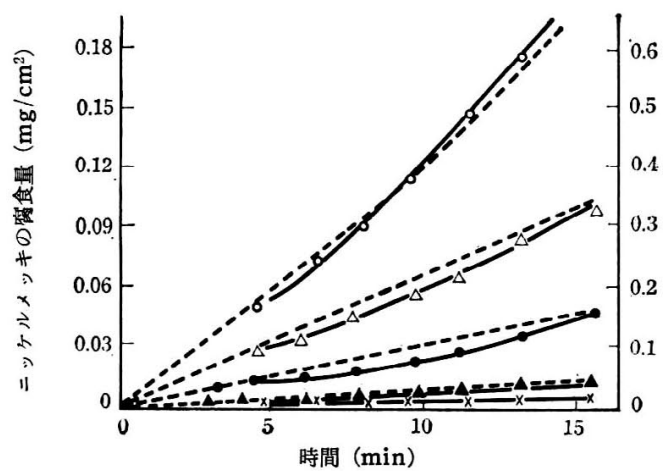

試料 $\mathrm{G}: \mathrm{O}: \mathrm{B}-\mathrm{E}, \triangle \mathrm{B}-\mathrm{B} \mathrm{D}_{1}$,

: $\mathrm{B}-\mathrm{D}_{2}, \quad \mathrm{~A}: \mathrm{B}-\mathrm{D}_{3}$,

$x: B-F$

……電気量

図 7 ニッケルークロムメッキにおけるニッケル の腐食速度

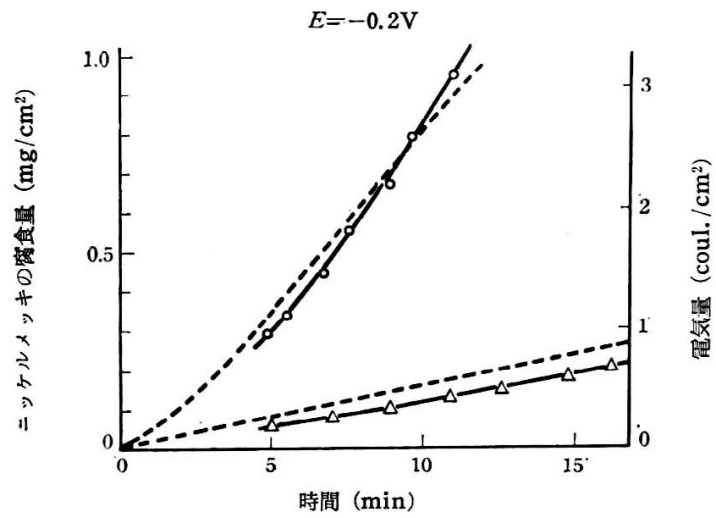

試料 $\mathrm{G}: \mathrm{O}: \mathrm{C}-\mathrm{E}, \triangle \mathrm{C}-\mathrm{D}_{2}$ …電気量

図 8 ニッケルークロムメッキにおけるニッケル の腐食速度

$$
E=-0.2 \mathrm{~V}
$$

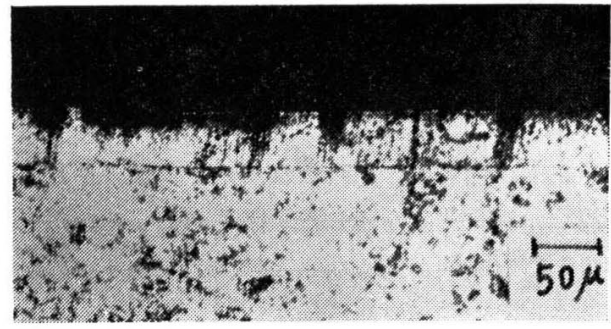

(a) 試料 $\mathrm{A}-\mathrm{D}_{2}$

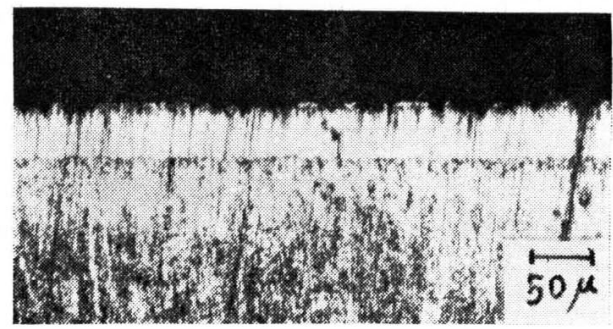

(b) 試料 $\mathrm{A}-\mathrm{E}$

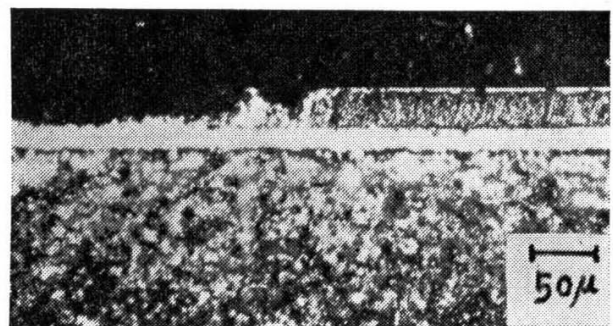

(c) 武料 $\mathrm{B}-\mathrm{D}_{2}$

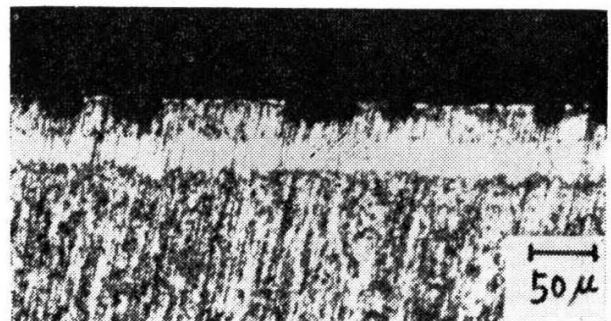

(d) 試料 $\mathrm{B}-\mathrm{E}$

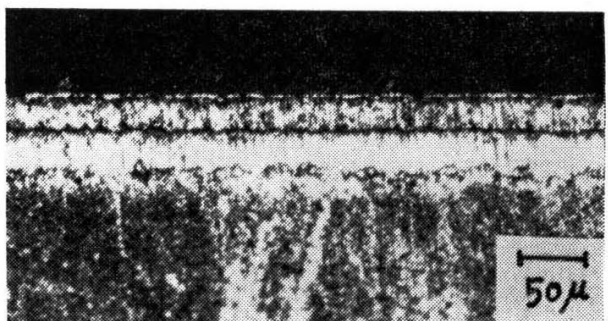

(e) 武料 B-F

写真 1 ニッケルークロムメッキ試料の腐食断面写真 電解液: $0.05 M / l-\mathrm{Na}_{2} \mathrm{SO}_{4}-\mathrm{H}_{2} \mathrm{SO}_{4}\left(\mathrm{pH}=1\right.$, 温度 $\left.25^{\circ} \mathrm{C}\right)$ 中 にわいて電位 $-0.2 \mathrm{~V}$ (vs. SCE) で 15 分間電解したニッケ ル十クロムメッキ 試料 $\mathrm{G}\left(\mathrm{A}-\mathrm{D}_{2}, \mathrm{~A}-\mathrm{E}, \mathrm{B}-\mathrm{D}_{2}, \mathrm{~B}-\mathrm{E}, \mathrm{B}-\mathrm{F}\right)$ 
序で小さくなっていることがわかる。クロムメッキのク ラックあるいはピンホールは $\mathrm{E}, \mathrm{D}_{1}, \mathrm{D}_{2}, \mathrm{~F}$ の順序で減少 しているが，このような欠陷を通して起こるニッケルメ ッキの腐食量は, 欠陥の数に比例するものと考えられる。

図 7 および図 8 は，それぞれニッケルメッキBおよび Cの場合の腐食速度を示した。図 7 および 8 からわかる ように, 電解時間が長くなるとニッケルメッキの腐食量 と時間とのあいだに直線関係が成立しないが，クロムメ ッキの種類によってニッケルメッキの腐食量が変化する 様子は, 図 6 の場合と同様である。また, クロムメッキ の種類が同じであればニッケルメッキの腐食速度はニッ ケルメッキの種類によって異なり,たとえば $\left(\mathrm{A}-\mathrm{D}_{2}\right)$, $\left(\mathrm{B}-\mathrm{D}_{2}\right),\left(\mathrm{C}-\mathrm{D}_{2}\right)$ の順序で増大し, これは図 1 で示し たニッケルメッキの活性態における腐食速度の順序と一 致している。このように,ニッケルークロムメッキ試料に おけるニッケルの腐食速度は，ニッケルメッキの性質な らびにクロムメッキの久陥の分布状態によって左右され ることがわかった。

写真 1 は, 電位 -0.2 V (vs. SCE) において電解した ニッケルークロムメッキ試料の断面におけるニッケルメ ッキ層の腐食孔の分布状態を示した。

これらの写真において，マイクロクラッククロムメッ キ $\mathrm{E}$ を行なった試料 $(\mathrm{A}-\mathrm{E})$ および $(\mathrm{B}-\mathrm{E})$ と，サー ジェント型のクロムメッキDを行なった試料 $\left(\mathrm{A}-\mathrm{D}_{2}\right)$ および $\left(\mathrm{B}-\mathrm{D}_{2}\right)$ とを比べると，前者では同じ大きさの 孔がほぼ均一に分布しており，単位長さあたりの腐食孔 の数が多いことがわかる。図6〜8に示したように，硫 黄を含む二ッケルメッキ B は試料 $\mathrm{A}$ と比べると腐食速度 がかなり大きく，このことはこれらの断面写真において 試料 $\mathrm{B}$ の腐食孔がAの場合より大きいことと対応してい る。一方，クラックフリークロムメッキFを行なった試 料の場合には腐食孔は著しく小さいことが羿められる。

表 2 は，一定時間電解を行なった後のニッケルメッキ の腐食量 $(Q)$ とニッケルークロムメッキにおけるニッケ

表 2 ニッケルメッキにおけるニッケルの溶解量 $Q$ と, ニッケル十クロムメッキにおけるニッケ ルの溶解量 $Q^{\prime}$ の比の時間的变化 試料 $\mathrm{A}, \mathrm{B}, \mathrm{G}\left(\mathrm{A}-\mathrm{D}_{2}, \mathrm{~A}-\mathrm{E}, \mathrm{B}-\mathrm{D}_{2}, \mathrm{~B}-\mathrm{E}\right)$ $E=-0.2 \mathrm{~V}$

\begin{tabular}{|c|c|c|c|c|c|}
\hline$\widehat{Q / Q^{\prime}} \quad$ 時間 $(\mathrm{min})$ & 1 & 5 & 10 & 15 & 60 \\
\hline$\frac{Q_{A}\left(\mathrm{mg} / \mathrm{cm}^{2}\right)}{Q_{A-D_{2}}^{\prime}\left(\mathrm{mg} / \mathrm{cm}^{2}\right)}$ & 12.8 & 13.9 & 14.2 & 13.8 & 13.6 \\
\hline$\frac{Q_{A}}{Q_{A}^{\prime}-E}$ & 1.3 & 1.2 & 1.4 & 1.2 & 1.3 \\
\hline$\frac{Q_{B}}{Q^{\prime} B-D_{2}}$ & 17.5 & 17.5 & 14.5 & 13.6 & 12.9 \\
\hline$\frac{Q_{B}}{Q^{\prime} B-E}$ & 9.5 & 8.2 & 7.1 & 6.0 & 4.3 \\
\hline
\end{tabular}

ルの腐食量 $\left(Q^{\prime}\right)$ との比を示したものである。 ニッケルメッキがA では, $Q_{A} / Q_{A-D_{2}}$ あるいは $Q_{A} /$ $Q_{A-E}^{\prime}$ の值はほとんど一定と見なされる。これに対し， 図 2 および図 5 に示したように二ッケルメッキの腐食速 度が比較的大きい $\mathrm{B}$ の場合には， $Q_{B} / Q_{B-D_{2}}$ あるいは $Q_{B} / Q^{\prime}{ }_{B-E}$ の值が時間とともに減少している。このこと は, 図 5 に示したように，窝食量と時間との間に值線関 係が成立しないことと対応しており，腐食孔内の面積が 時間とともに著しく増大するものと考えられる1,13)。二 ッケルメッキの腐食量が時間とともに著しく増大するこ とは, 図6の結果からはっきり認められる。

このような電気化学的方法によるニッケルメッキの腐 食孔の発生ならびに腐食形態は, 従来の加速腐食試験あ るいは大気暴露試験における結果とよく対応しており, 腐食孔の発生機構についても同一の反応によって説明で きるものと考元られる1,7,14)。

以上のことから,ニッケルークロムメッキのニッケルメ ッキ層における腐食孔は, 腐食環境において新たに生じ うるものであり，メッキ直後にニッケルメッキ層に欠阷 が存在しなくても，クロムメッキ層の欠陷においてニッ ケルメッキの腐食が起こり，腐食孔として内部に拡が り，それが素地金属まで達するものと考えられる。

写真 2 に,クロムメッキ $\mathrm{D}_{2}$ および $\mathrm{E}$ の表面における クラックの分布状態を示した。これは $0.05 \mathrm{M} / l \mathrm{Na}_{2} \mathrm{SO}_{4}$

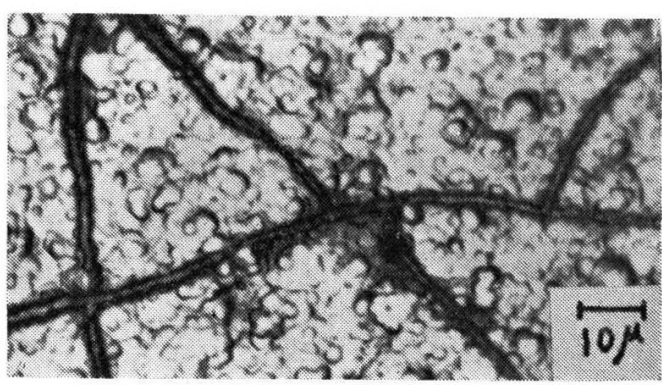

(a) 試料 $\mathrm{D}_{2}$

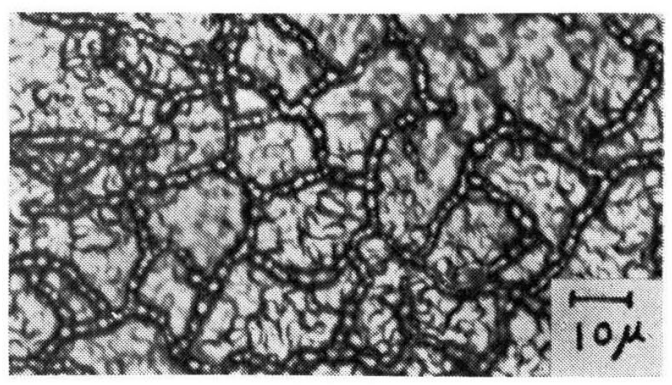

(b) 試料 $\mathrm{E}$

写真 2 クロムメッキ表面におけるクラックの分布状況 $0.05 M / l-\mathrm{Na}_{2} \mathrm{SO}_{4}-\mathrm{H}_{2} \mathrm{SO}_{4}$ 中に扔いてクロムメッキを+0.9 V (vs. SCE) で 30 秒間電解したのち, $\mathrm{CuSO}_{4} \cdot 5 \mathrm{H}_{2} \mathrm{O} 200 \mathrm{~g} / l+$ $\mathrm{H}_{2} \mathrm{SO}_{4} 150 \mathrm{~g} / l$ 中で銅を電着した。

電流密度 $6 \mathrm{~mA} / \mathrm{cm}^{2}$, 温度 $30^{\circ} \mathrm{C}$ 
$-\mathrm{H}_{2} \mathrm{SO}_{4}$ 中において, クロムメッキを過不働態電位 +0.9 $\mathrm{V}$ (vs. SCE) で 30 秒間電解したのち, 硫酸銅 $200 \mathrm{~g} / l$, 硫酸 $150 \mathrm{~g} / l$ を含む溶液中で, クラックの部分に銅を電 着したものである。試料 $\mathrm{D}_{2}$ では比較的大きなクラック が不均一に分布しているが，試料 $\mathrm{E} て ゙ は$ 細かなクラック が多数存在することがわかる。これらの表面写真からク ラックの数を求めると, $\mathrm{D}_{2}$ では $100 \sim 120$ 個 $/ \mathrm{cm}^{2}, \mathrm{E}$ で は 600 700 個 $/ \mathrm{cm}^{2}$ となる。これは現在一般に行なわれ ているクロムメッキのクラック数に相当する14)。

以上の実験から, ニッケルークロムメッキにおいては, クロムメッキ層に欠陥が比較的少ない場合にはニッケル の総腐食量は小さく, 一方, 腐食孔の分布状態はクロム メッキ層のクラックの分布状態に相応することが認めら れた。このことは, クロムメッキ層に欠陥が存在しなけ れば下地のニッケルメッキ層および素地金属はほぼ完全 に保護されることを示す。クロムメッキ層で, ニッケル メッキ層に通ずる欠陷が存在する場合には, ニッケル上 で起こる局部カソード反応にさらにクロムメッキ層で起 こるカソード反応が加わるので, ニッケルの腐食反応は 促進されるものと考えられる13)。

現在行なわれている二層ニッケルメッキにおいては, クロムメッキ層に存在するクラックの分布状態ならびに ニッケルメッキの性質を考慮して, 硫黄を含まないレベ リングのよい半光沢ニッケル上に硫黄を含む光沢ニッケ ルを行なっているので，クロムメッキがカソードとして 作用しうる腐食環境において, 反応性の高い硫黄を含有 するニッケルメッキ層が優先的に溶解し，下地のニッケ ルメッキの腐食が抑制されるものと説明できる。この場 合, クロムメッキ層にマイクロクラッククロムメッキを 用いれば局所的に大きな腐食孔注発生しなく，比較的小 さな孔を均一に分布させることができるが, ニッケルの 総腐食量は, 普通のクロムメッキを用いた場合より, 大 きくなる傾向がある。

\section{4. 総 括}

（1）有機添加剤を含まないワット浴から得られるニッ ケルメッキは不働態化しやすいが, 有機添加剂を加えて 得られる光沢あるいは半光沢ニッケルメッキは活性態に おける腐食反応が促進され，不動態化が抑制される。こ れはメッキ中に共析した硫黄あるいは炭素化合物の影響 によるものと考えられる。
(2) クロムメッキはニッケルメッキより亀な電位で不 働態化するので, ニッケルメッキの活性態の電位はクロ ムメッキの不働態の電位に含まれることになる。したが って, ニッケルメッキの活性態電位において, クロムメ ッキの腐食速度は著しく小さくなりクロムメッキのクラ ックやピンホールの部分におけるニッケルメッキの腐食 速度を定電位電解法によって測定できる。

(3) ニッケルークロムメッキにおけるニッケルメッキ の腐食速度は, ニッケルメッキの性質ならびにクロムメ ッキの欠陥の分布状態に依存し, クロムメッキ層の欠樎 の数が多くなるほどニッケルメッキ層の腐食速度が増大 し，このような傾向は硫黄を含むニッケルの場合さらに 促進されることがわかった。

（4）定電位電解を行なったニッケルークロムメッキに おけるニッケル層の腐食孔はほぼ半球状であり, 時間と ともにとの径が増大することがわかった。このことから ニッケルメッキ層に欠㻪が存在しなくても, クロムメッ キの欠陥の部分において腐食孔は新たに生じうるもので あり，腐食孔が時間とともに内部へ拡がり素地に達する ものと考えられる。

（5）二層ニッケルメッキ系において用いられる上層の 硫黄を含む光沢ニッケルメッキは, 硫黄を含まない下層 より腐食速度が大きいので優先的に腐食され, 素地への. 腐食の進行が抑制されるものと考えられる。

\section{(昭和 41 年 3 月 15 日受理)}

\section{文献}

1) G. N. Flint \& S. H. Melbourne: Trans. Inst. Metat Finishing, 38, 35 (1961); 39, 85 (1962)

2) W. A. Safranek, et al.: Plating, 47, 514 (1960)

3) J. V. Petrocelli, et al. : ibid., 49, 50 (1962)

4) A. H. du Rose: Proc. Amer. Electroplators' Soc., 47, 82 (1960)

5) T. P. Hoar: Discussion Faraday Soc., No. 1, 229 (1947)

6) W. A. Wesley: "Corrosion Handbook", Ed. by H. H. Uhlig, John Wiley \& Sons, N. Y. p. 481 (1948)

7) W. A. Wesley: Proc. Am. Electroplators' Soc., 50, 9 (1963)

8）前田正雄：“電極の化学”, p.332, 技報堂 (1962)

9）岡本剛，佐藤教男：“防食技術の進歩”, p. 18, 日本学術振興会編 丸善 (1963)

10) E. Raub \& A. Disam: Metaloberfläche, 15, 193 (1961)

11) H. G. Weidinger \& E. Lange: $Z$. Elektrochem., 64, 468 (1960)

12) 岸松平: 応用物理, 12, 479 (1943)

13) K. Müller: Werks. Korr., 14, 88 (1963)

14) F. L. LaQue: Trans. Inst. Metal Finishing, 41, 127 (1964) 